\title{
JAMES PRENDERGAST AND THE TREATY OF WAITANGI: JUDICIAL ATTITUDES TO THE TREATY DURING THE LATTER HALF OF THE NINETEENTH CENTURY
}

\author{
Grant Morris*
}

Chief Justice James Prendergast has largely been demonised over the last two decades as a result of his famous decision in the Wi Parata v The Bishop of Wellington case in 1877. In that decision, he notably stated that the apparent cession of sovereignty in the Treaty of Waitangi was "a simple nullity". This statement has effectively taken on a life of its own, and is still cited - with polarising effect - in the current debate on the place of the Treaty in modern New Zealand society. The author argues, however, that the debate and commentary on the case has largely omitted to consider Prendergast as a man of his times and background and as an important part of a small legal community. The part that others had to play in the Wi Parata case is often not mentioned, for example. This article seeks to redress the balance somewhat. In doing so, it does not underestimate the devastating effect which the decision had in supporting the alienation of Maori land. However it emphasises that Prendergast's view represented the orthodoxy of the time, and for some considerable time thereafter, and that his main fault was that he failed to rise above the prejudices of the settler society in which he lived.

1 INTRODUCTION

In recent decades, New Zealand as a nation has increasingly focused on Maori and Pakeha relations. Dominating the debate has been the Treaty of Waitangi, an agreement between Maori and the British Crown, signed in 1840. This debate has taken many forms: political argument, academic analysis and legal reasoning. The Treaty debate has also transformed a late nineteenth century New Zealand Supreme Court case into the most notorious judicial decision in New Zealand history. In

* Lecturer in Law, Victoria University of Wellington. 
1877 Chief Justice James Prendergast declared in the case, Wi Parata $v$ Bishop of Wellington ${ }^{1}$ that the Treaty of Waitangi was "a simple nullity". This decision heavily influenced New Zealand law until directly challenged during the mid-1980s.

While Prendergast's career included many important achievements, it is his decision in the Wi Parata case for which he is best remembered. Although the Wi Parata decision has been discussed at length by various legal commentators, Prendergast's specific role in the decision has not yet been viewed in historical context. Research into the context of Prendergast's decision aids in providing what has been, up till now, a two-dimensional legal event, with an important third dimension. To understand and appreciate the complexities of the pivotal decision, it is vital to know the relevant background facts to both Prendergast the man and the case itself. A close textual analysis of the decision reveals that there is much that this narrow focus has obscured.

A brief outline of the decision's influence will be provided to assess its historical legacy, and modern academic opinion will be explored. Finally, this paper will provide a tentative assessment of the role of Prendergast in this controversial decision and his role in creating legal boundaries between Maori and Pakeha.

\section{BACKGROUND TO THE CASE}

\section{A The Career of James Prendergast}

A highlighting of certain events in James Prendergast's background is important in helping to view the Wi Parata decision in context. Prendergast was born in London when it was the heart of the global British empire; a direct contrast to the colonial society where he would eventually achieve prestige and power. James Prendergast had all the educational opportunities a young middle-class Englishman needed to pursue a successful career. He attended St Paul's School and Cambridge University. His father was the high-profile and controversial English Queen's Counsel, Michael Prendergast. One of James Prendergast's uncles was a leading classical scholar, and another one of the foremost English portrait artists of the time. The young Prendergast was no stranger to tragedy with the death of his sister and mother during the 1840s. In his early twenties, he already demonstrated an ambitious and resourceful personality. ${ }^{2}$ In 1852, he married Mary Hall of Cambridgeshire.

The first experience Prendergast had with colonial frontier society was his bold and adventurous decision to join the gold rushes in Victoria, Australia during the early 1850s. Soon after arriving in Victoria, he contracted dysentery and almost died. A fortune made from gold-mining proved elusive and he began to appreciate the awesome challenges facing colonists in a new and alien

1 (1877) 3 NZ Jur (NS) 72 (SC).

2 James Prendergast, University of Cambridge to father Michael Prendergast QC (1846-1850) Personal Letters (Wellington, Alexander Turnbull Library, MS-1791). 
land. ${ }^{3}$ Prendergast returned to London three years later to be called to the English Bar. While he demonstrated an aptitude for the legal art of special pleading, he did not secure the amount of work he desired, largely due to the over-crowding of the English legal profession during this period. ${ }^{4}$ After the death of his father in 1859, Prendergast lost his legal mentor. His elder brother, Michael, travelled to New Zealand in the early 1860s and wrote to James to join him as soon as possible. Career frustration and the loss of his father finally led James to leave England for New Zealand in 1862. He embarked upon his second adventure to the colonies of the British Empire and arrived in Dunedin in November 1862 to begin work as a New Zealand lawyer. ${ }^{5}$

Prendergast's experience at the English bar, combined with his diligence and legal prowess, provided an excellent basis for success in Dunedin. After his experience in Victoria, he had learned that it was more lucrative supporting the gold-miners rather than actually working as a gold-miner. Aside from being a busy lawyer, he also served as the Acting Provincial Solicitor and Crown Solicitor for the Otago Province. After only three years as a successful Otago barrister, he was appointed Attorney-General. From 1865 to 1867, Prendergast served in the Legislative Council, but thereafter the role of Attorney-General was a non-political one. As Attorney-General, he was responsible for over-seeing the drafting of a large amount of legislation, especially in the areas of criminal and land law. Much of this legislation was heavily reliant on English statutory precedents.

Prendergast became well-known for his hardline approach in dealing with the later stages of the New Zealand Wars during the late 1860s. ${ }^{6}$ As Attorney-General, he upheld the legality of an official death warrant for Titokowaru and successfully prosecuted Te Kooti's follower, Hamiora Pere, who received the death penalty. This period in New Zealand history saw armed conflict between Imperial Britain and colonial settlers on one side and Maori fighting to retain land and sovereignty on the other. The views on race relations formed by Prendergast during his time as Attorney-General would influence his decisions as Chief Justice. These views would also influence him when authorising the invasion of Parihaka in 1881, while acting-Governor.

As a judge, Prendergast was comprehensive, cautious and conservative. In many cases, including Wi Parata, he had the opportunity to interpret legislation that he had been involved in formulating while Attorney-General. He was an effective administrator as Chief Justice and was well-regarded by his judicial colleagues. On his retirement, Prendergast served on several Boards of

3 James Prendergast, Victoria, Australia to Michael Prendergast QC, London (1852-1855) Personal Letters (Wellington, Alexander Turnbull Library, MS-1791).

4 David Duman The English and Colonial Bars in the Nineteenth Century (Croom Helm, London, 1983).

5 (21 November 1862) Otago Daily Times Dunedin 4.

6 Judith Bassett and J G H Hannan "James Prendergast" in WH Oliver and Claudia Orange (eds) Dictionary of New Zealand Biography: Volume 1, 1769-1869 (Allen \& Unwin/Department of Internal Affairs, Wellington, 1990) 355. 
Directors and represented the Seddon Government at the 1901 Imperial Conference on the Privy Council. $^{7}$

In 1875 he was made New Zealand's third Chief Justice, a spectacular rise for the ambitious colonist. $^{8}$ By this stage in his career, James Prendergast had become a key figure in the New Zealand settler establishment with a firm commitment to creating a stable and prosperous colonial society free from dissension. As Chief Justice, he demonstrated a pragmatic and often conservative approach to judicial decision-making. After two years of his twenty-four year career as Chief Justice, Prendergast and his Wellington judicial colleague, Christopher William Richmond, heard the case of Wi Parata v Bishop of Wellington in 1877.

\section{B Background to the Wi Parata Fact Situation}

The facts of the case stretched back almost three decades to a period of increasing European dominance in New Zealand. In 1848 the Ngati Toa tribe in the south-west of the North Island reached an agreement with the Anglican Bishop of New Zealand to place a parcel of land in Porirua aside for educational purposes. This land was held under native or aboriginal title. In 1850 Governor George Grey issued a Crown Grant to the Bishop without the consent of Ngati Toa. ${ }^{9}$ During the intervening twenty-seven years, no school had been established and Maori numbers in the area had substantially diminished. Wi Parata, a Maori member of Parliament and a Ngati Toa chief, decided to take the case to the Supreme Court in an attempt to recover the entrusted land for his tribe. ${ }^{10}$ Parata had become prominent in the support of Maori land cases and was aware of the importance that would be attached to this particular case.

The facts behind the 1877 decision were not unique and therefore served as a test case for similar situations in the colony. A Royal Commission in 1869 had shown that many similar trusts around the colony had also failed to achieve their purpose. As Frederika Hackshaw has argued: ${ }^{11}$

The political implications of that claim are self-evident: a favourable decision for the plaintiff would open the floodgates to native demands for the return of every similarly situated trust property.

7 Grant Morris Chief Justice James Prendergast and the Administration of New Zealand Colonial Justice, 1862-1899 (PhD thesis, University of Waikato, 2001) 260-264.

8 "The New Chief Justice" (1865-1875) Colonial Law Journal 24-26.

9 Grey to Selwyn "Wi Parata versus the Bishop of Wellington and Others" (28 December 1850) Papers (Church of the Province of New Zealand, Wellington Diocese: Further records (89-008) Wellington, Alexander Turnbull Library).

10 Wi Parata above n 1, 72.

11 Frederika Hackshaw "Nineteenth Century Notions of Aboriginal Title and their Influence on the Interpretation of the Treaty of Waitangi" in IH Kawharu (ed) Waitangi: Maori and Pakeha Perspectives of the Treaty of Waitangi (Oxford University Press, Auckland, 1989) 110. 
The case demonstrated that the issue of land ownership had the potential to unravel the delicate fabric of Pakeha society. Parata petitioned the Court for the return of the land to its original Maori owners on the basis that the grant had been issued without the tribe's consent and the expected school had not been built. ${ }^{12}$ The judges who were assigned the task of hearing Wi Parata's case were therefore adjudicating on a controversial issue, namely, the struggle for control of land between Maori and Pakeha.

\section{Other Key Players in the Wi Parata Decision}

Prendergast's present historical reputation rests on his decision in Wi Parata $v$ The Bishop of Wellington. Only a few legal commentators, when discussing the case, have emphasised that the decision was a cooperative effort made by two judges. ${ }^{13}$ Both James Prendergast and Christopher William Richmond were responsible for Supreme Court decisions in the Wellington judicial region from 1875. Richmond, like Prendergast, was an English lawyer from a privileged background. ${ }^{14}$ Arriving in New Zealand in 1853, Richmond and the extended Richmond-Atkinson family secured a leading position in colonial politics. The blame for the controversial and bloody Taranaki War (1860-61) has been partly attributed to Richmond by some commentators. ${ }^{15}$ The Taranaki War left a legacy of misunderstanding and distrust between Maori and Pakeha. Richmond was also no stranger to difficult decisions regarding Maori land rights. During his time as Minister of Native Affairs (1858-60), he demonstrated a hard-line, unsympathetic attitude towards Maori. ${ }^{16}$ He began his judicial career in 1861 and was an original member of the New Zealand Court of Appeal when it was first convened in 1863 . When viewing the Wi Parata decision in context it is necessary to appreciate the supporting role of Richmond in formulating the Court's decision. To hold

12 Wi Parata, above n 1, 72-3.

13 See David Williams "Te Tiriti o Waitangi - Unique Relationship Between Crown and Tangata Whenua?" in Kawharu (ed), above n 11, 87; EJ Haughey "A Vindication of Sir James Prendergast" 1990 NZLJ 230. Also discussed in my earlier chapter on this subject: Grant Morris "'The Final Legal Frontier': the Treaty of Waitangi and the Creation of Legal Boundaries between Maori and Pakeha in New Zealand Society" in Lynette Russell (ed) Colonial Frontiers: Indigenous-European Encounters in Settlers Societies (Manchester University Press, Manchester, 2001) 122.

14 Judith Bassett Sir Harry Atkinson, 1831-1892 (Auckland University Press, Auckland, 1975) 2-5.

15 See principally early New Zealand historians such as Saunders, Rusden and Miller, but also contemporaries such as William Martin and Octavius Hadfield. Richmond's critics are answered and his conduct defended in William Downie Stewart Mr. Justice Richmond and the Taranaki War of 1860: A Great Judge Vindicated (Whitcombe \& Tombs, Wellington, 1945) especially 7-9.

16 Keith Sinclair outlines Richmond's views in WH Oliver and Claudia Orange (eds) Dictionary of New Zealand Biography: Vol 1 364, "Richmond wanted to destroy what he called the 'beastly communism' of Maori society by introducing private property in land ... . Richmond knew almost nothing about Maori culture or land tenure. He simply believed that it was necessary to 'civilise' the Maori, that is, to lead them to adapt British habits and practices." While Native Minister, Richmond attempted to overthrow Crown pre-emption, thus challenging Article Two of the Treaty. 
Prendergast totally responsible for the final decision in the case would reflect an inaccurate view on judicial decisionmaking.

The judicial careers of Prendergast and Richmond are closely intertwined. Both judges served on the Court of Appeal bench and in the Wellington division of the Supreme Court. For twenty years (1875-1895) the two men adjudicated together in the Wellington area. The Wi Parata decision was formulated near the beginning of Prendergast's twenty-four year tenure as Chief Justice and at the beginning of his professional relationship with Richmond. While both judges were responsible for the decision, Prendergast officially delivered it in court. It is difficult to know just how much influence Richmond had in aiding Prendergast, as the two men were still fine-tuning their working relationship in 1877 . While Richmond had fourteen years more judicial experience than Prendergast, the Chief Justice was an assertive individual, aware of his position and role.

It is possible that Prendergast's decision in Wi Parata was part of an attempt to assert his authority as the head of the New Zealand judiciary. The decision comes early in his judicial career and the relative inexperience of the Chief Justice must be taken into consideration when evaluating the quality of the legal reasoning. In fact, his competency as Chief Justice was about to be placed in serious question, only a few months after the Wi Parata decision was delivered. The man responsible for formulating the most serious allegations that Prendergast had ever faced, happened to be one of the advocates in the Wi Parata case, George Barton.

George E Barton, an Irish lawyer, was the barrister for the plaintiff, Wi Parata. Barton was a colourful character, often finding himself at the centre of controversy. ${ }^{17}$ Like Prendergast and Richmond, Barton was no stranger to colonial society. He was involved in law and politics in both Australia and New Zealand having practiced in Melbourne and Dunedin. He was also familiar with James Prendergast and his brother Michael. During 1877, he was prominent in a number of important Supreme Court cases tried in Wellington. A clash of personalities had seen a bitter feud develop between Barton and the two judges, Prendergast and Richmond. Indeed, only two months before the decision in Wi Parata was handed down, Barton had submitted a formal petition to Parliament to force the resignation of Prendergast and Richmond for alleged bias against Barton and his clients as well as citing the judges to be guilty of judicial incompetence. ${ }^{18}$ In January of 1878 Barton would make colonial legal history for being found in contempt of court by Prendergast and imprisoned for one month. ${ }^{19}$ The experience of Chief Justice Prendergast and Richmond with

17 Iain Gallaway "Otago" in Robin Cooke (ed) Portrait of a Profession: The Centennial Book of the New Zealand Law Society (Reed, Wellington, 1969) 332.

18 Report on Petition 172 - GE Barton complaining of improper and partial conduct on part of certain judges of Supreme Court and asking for inquiry and relief [1877] AJHR, 1877 I 27.

19 This occurred during the case Gillon v MacDonald (1878) discussed in (February 1878) New Zealand Jurist 28. While in prison, Barton won the parliamentary seat for Central Wellington, replacing Travers as Member of Parliament for this high profile seat. 
Maori affairs and their bitter relationship with Barton must be considered a factor when analysing the nuances of the Wi Parata decision. ${ }^{20}$

Indeed, the Wi Parata decision featured a kaleidoscope of prominent New Zealand public figures. In addition to Prendergast, Richmond and Barton, the case also involved William Travers and Charles Izard, and, of course, the plaintiff himself. Wi Parata was a Ngati Toa leader and spokesman who had also served in Parliament during the 1870s. A vocal supporter of Maori issues, "[h]e expressed the view that the law-makers were making decisions affecting Maori without understanding them." 21 On his departure from Parliament, Parata championed Maori land cases, most famously the 1877 landmark case regarding the Ngati Toa land in Porirua. In the Wi Parata case, Parata was representing the Ngati Toa tribe: "Quære, whether a Maori chief can sue on behalf of his tribe....Prayer:--1. That the lands may be declared to be part of the native lands lawfully reserved for the use and benefit of the Ngatitoa tribe." 22 In the same way the Attorney General in the case represented the Crown. Parata's commitment to Maori justice was further demonstrated by his support of Te Whiti at Parihaka. Parata was present at Parihaka in 1881 when the Taranaki village was invaded following Prendergast's proclamation. ${ }^{23}$

The legal advocates involved in the Wi Parata decision were all leading figures at the Wellington bar: George Barton from the firm, Barton and Fitzherbert (plaintiff); William Travers from the firm Travers, Ollivier and Co (defendant, Bishop of Wellington); and Charles Izard (defendant, Attorney-General). Barton was by far the most volatile of the lawyers present. William Travers was also an Irish lawyer who had come to New Zealand in 1849 and experienced a disjointed career in Parliament. During 1877, the year in which the Wi Parata case was heard, Travers was the member of the House of Representatives for Wellington City. ${ }^{24}$ Therefore, Travers was a member of the Government attempting to acquire more Maori land while acting as an advocate in a decision which enabled the acquisition of Maori land.

In 1870, Prendergast and Travers worked together on the first New Zealand Law Society Council. ${ }^{25}$ When James Prendergast was formally congratulated for his time as Administrator during and after the tenure of Governor Gordon, a group of private citizens was there to pay

20 Barton later served as a judge of the Native Land Court and in 1892 a judge of the validation court. Although working in the area of Maori land, Barton could not be seen as especially sympathetic to Maori concerns.

21 Hohepa Solomon "Wiremu Te Kakakura Parata" in Claudia Orange (ed) The Dictionary of New Zealand Biography, Volume II 1870-1900 (Bridget Williams/Department of Internal Affairs, Wellington, 1993) 375.

22 Wi Parata, above n 1, 72-73.

23 Solomon, above n 21, 375.

24 Winsome Shepherd "William Thomas Locke Travers" in Oliver and Orange (eds), above n 6, 547.

25 Cooke (ed), above n 17, 146. 
respects, including Travers. While it is unclear whether Prendergast and Travers were friends, a degree of respect existed in their relationship which was clearly absent in the case of George Barton and Prendergast. Travers also had the respect of the wider legal profession and during the controversy following the Privy Council's Wallis decision in 1903 was described as "the doyen of the local Bar."26

Charles Izard was another established Wellington practitioner. An English lawyer with a specialist knowledge of equity, Izard had been a leading figure at the Wellington bar since its earliest days. He was also partly responsible for the creation of today's large law firm, Bell Gully, which he helped create alongside Sir Francis Dillon Bell. ${ }^{27}$ Izard was a political conservative and supporter of Harry Atkinson. ${ }^{28}$

The offending Crown Grant which effectively provided the basis for the Wi Parata case, and the following Privy Council cases, Nireaha Tamaki v Baker ${ }^{29}$ and Wallis v Solicitor-General, ${ }^{30}$ was given by Governor George Grey to Bishop George Augustus Selwyn. Grey's relationship with the Maori ranged from meticulously recording their oral history to invading their tribal lands during the Waikato War. Selwyn, a key missionary figure in New Zealand history, was committed to the welfare and conversion of Maori but found himself torn between Government and Maori during the New Zealand Wars. ${ }^{31}$ Selwyn was the Bishop of Wellington in 1850, while in 1877 the Bishop was the high-profile and widely-respected Octavius Hadfield. While Hadfield was an outspoken supporter of Maori in the Porirua-Otaki region, the Anglican church found itself directly in conflict with Ngati Toa in the Wi Parata case.

Analysis of the main players in the Wi Parata affair aids in viewing the case in context. The antagonistic behaviour of Barton throughout 1877 towards Prendergast and Richmond, and the intense frustration that the new Chief Justice experienced in response, is not evident in a reading of the official law reports. The dry manner in which many decisions were written and recorded during Prendergast's era masks the personalities and rivalries of those involved in creating the decision. While the legal system strives for objectivity, the system is comprised of individuals, with individual personalities and backgrounds. These factors may affect a legal decision to varying extents, but even if their influence is limited they provide context for what appears in the law

26 Cooke (ed), above n 17, 140.

27 GH Scholefield (ed) A Dictionary of New Zealand Biography (Department of Internal Affairs, Wellington, 1940) 431.

28 Scholefield (ed), above n 27, 431.

29 Nireaha Tamaki v Baker (1900-01) NZPCC 371.

30 (1902-03) NZPCC 730.

31 Warren E Limbrick "George Augustus Selwyn" in Oliver and Orange (ed), above n 6, 388. 
reports. But the individuals prominent in the Wi Parata decision were also representatives of larger groups in colonial New Zealand society. Prendergast and Richmond represented the legal system of New Zealand, Parata and Barton represented the Ngati Toa tribe, Travers spoke on behalf of the Anglican Church while Izard was the advocate for the New Zealand Government. These large and powerful forces in New Zealand colonial society met in the Wellington Supreme Court in 1877.

\section{THE JUDGMENT}

The judgment in Wi Parata $v$ Bishop of Wellington was far from just a simple one-line quotation. The judgment of Sir James was complex and discussed a variety of related issues. The ruling stated that unless native customary title was supported by a Crown Grant it could not be accepted or enforced by the Courts. The imposition of British legal theories upon Maori landownership would result in the loss of much Maori land and give the impression that 'English law' was a tool to aid in dispossession. The Crown Grant made to the Bishop was unable to be annulled by the Court and the existence of this grant implied that the Crown had used its sovereign powers to extinguish any existing native title. When the Crown acquired the North Island of New Zealand by occupation and the South Island by discovery, it also acquired the exclusive right of extinguishing aboriginal title. By effectively deeming the South Island terra nullius, the Maori iwi, Ngai Tahu, who were living in the South Island at the time of European arrival became a casualty of a broad and sweeping system of extinguishment. The Crown's right to extinguish aboriginal title was accompanied by a treaty-like duty to protect Maori against infringement of their right of occupancy. Land transactions with Maori were a matter for the Crown only, and the Court had no jurisdiction to diminish the Crown powers. ${ }^{32}$

Instead of only discussing the nature of Crown Grants and native title, however, Prendergast ventured beyond the scope of the mere facts of the case to pass judgment on the Treaty of Waitangi. Prendergast used the Wi Parata decision as an effective vehicle for enshrining eurocentric, imperialist views into law. To justify his opinion that New Zealand was acquired by occupation and discovery, vital to his reasoning, the Chief Justice had somehow to dispose of the Treaty. The method Prendergast used became the most notorious example of legal reasoning in New Zealand history. The Chief Justice stated that: ${ }^{33}$

So far indeed as that instrument [the Treaty] purported to cede the sovereignty - a matter which we are not here directly concerned - it must be regarded as a simple nullity. No body politic existed capable of making cession of sovereignty, nor could the thing itself exist.

In Prendergast's view, New Zealand was peopled only by "primitive barbarians" and "savages" who had no sovereignty to cede nor existing body of customary law that could be legally recognised.

32 Wi Parata, above n 1, 78-9.

33 Wi Parata, above n 1, 78. 
This primitive race was to be quickly subdued as New Zealand was transformed into a 'Better Britain'. ${ }^{34}$ After giving a landmark judgment on the most controversial aspect of New Zealand history, Prendergast returned to the specific facts. Prendergast applied the doctrine of cy prés ${ }^{35}$ and decided that the land would not revert to the surviving donors if cy prés was not possible, but to the Crown. ${ }^{36}$

While Prendergast adjudicated upon several issues relating to Maori land, the Wi Parata decision is remembered for three words, 'a simple nullity'. If these three words were preceded by 'The Treaty of Waitangi is ...', all three articles of the Treaty, according to Prendergast, would be null and void. But Prendergast's judgment did not state this. Instead it related "nullity" to the ceding of sovereignty. Both the Maori and English versions of the Treaty discuss more than sovereignty. Other issues include possession of Maori land, forests, fisheries and other taonga, ${ }^{37}$ the Crown's preemptive right of purchase and the imparting of the rights and privileges of British subjects to Maori. ${ }^{38}$ A similar line of argument has been presented before by EJ Haughey and forces one to examine the exact language in the judgment in more detail. ${ }^{39}$ While there seems little doubt that the Chief Justice was seeking to sidestep the Treaty, he did not necessarily condemn it entirely. ${ }^{40}$ In his judgment, Prendergast made an attempt to widely canvass existing law, both statute and common. The effect of the judgment was to minimize the role of the Treaty and emphasise that the Treaty in itself had no binding force.

As a Legislative Councillor in 1865 during a debate on Maori representation in Parliament, Prendergast made an intriguing speech regarding the rights of Maori in New Zealand society: ${ }^{41}$

[T] here could be no doubt that, in the minds of all our friends at Home, the Natives have an inborn right, as British subjects, to the privileges of this country ... the Natives, who were the largest landholders in the colony, and he considered it was unjust that they should exist under such disabilities.

34 A phrase used frequently in James Belich Making Peoples: a History of the New Zealanders: from Polynesian Settlement to the End of the Nineteenth Century (Allen Lane/Penguin, Auckland, 1996).

35 Funds would be applied as near as possible to application specified by donor: Peter Spiller Butterworths New Zealand Law Dictionary (4 ed, Butterworths, Wellington, 1995) 80.

36 Wi Parata, above n 1, 72, 83.

37 Loosely translated as 'treasures'.

38 From the Texts of the Treaty of Waitangi (Text in English, Maori and Translation of Maori text by Kawharu) in IH Kawharu (ed) 316-21.

39 Haughey, above n 13, 230.

40 If Prendergast had attempted to nullify the entire Treaty he would have undermined the entire Crown preemption system (outlined in Article Two of the Treaty).

41 James Prendergast (1 August 1865) NZPD 208. 
Prendergast was arguing that Maori should have parliamentary representation, a view which appears at odds with his general disparaging attitude towards the Maori. Yet, in Wi Parata, Prendergast stated that Britain, by settling New Zealand assumed the duty: ${ }^{42}$

[A]s supreme protector of aborigines, of securing them against any infringement of their right of occupancy; -3 Kent, Com., ubi supra. The obligation thus coupled with the right of pre-emption, although not to be regarded as properly a treaty obligation, is yet in the nature of a treaty obligation.

This dutiful and paternalistic approach is a mark of British imperialism and control but could begin to undermine the view that Prendergast was blatantly "anti-Maori". 43

In the course of his Wi Parata judgment, Prendergast referred to previous landmark cases dealing with aboriginal title and the Treaty of Waitangi. He provided a confused reference to the 1847 New Zealand Supreme Court case of the Queen v Symonds. ${ }^{44}$ He stated that "Our view of this subject [indigenous peoples' rights] is in accordance with previous decisions of this Court."45 The Chief Justice then discussed the Symonds case as an apposite example, implying concurrence with its findings. Later in his judgment, though, Prendergast took issue with specific arguments made by Chapman J in deciding the Symonds case. ${ }^{46}$ Prendergast agreed with Chapman J's argument that the Treaty had affirmed rights already vested in the Crown but Peter Spiller argues that he 47

... [R] ejected Chapman J.'s statement that the American courts would allow a grant of land to be impeached by a native Indian, on the basis that the Indian title had not been extinguished. The

[Prendergast] court said that this was not a legitimate inference from the Commentaries of Kent.

Prendergast found both helpful and unhelpful statements in Chapman J's landmark decision. It is clear that Prendergast did not agree with Chapman J's views on aboriginal title and customary law. In the Wi Parata decision, Prendergast stated: "On the foundation of this colony, the aborigines were found without any kind of civil government, or any settled system of law... . The Maori tribes were incapable of performing the duties, and therefore of assuming the rights, of a civilised community". ${ }^{48}$ Prendergast did not accept that Maori customary law could exist. According to the Chief Justice, references to customary law found in section 3 of the Native Rights Act 1865 were inapplicable: "The Act speaks further on of the 'Ancient Custom and Usage of the

42 Wi Parata, above n 1, 78-9.

43 Ranginui Walker Ka Whawhai Tonu Matou: Struggle Without End (Penguin Books, Auckland, 1990) 158.

45 Wi Parata, above n 1, 78.

Wi Parata, above n 1, 80 .

47 Peter Spiller "Chapman J and the Symonds Case" (1990) 4 Cant LR 257, 264.

48 Wi Parata, above n 1, 77. 
Maori people,' as if some body of customary law did in reality exist. But a phrase in a statute cannot call what is non-existent into being". 49

Customary law can be differentiated from aboriginal or native title by arguing that customary law is a uniquely Maori construction while aboriginal title is a common law doctrine imported from Europe. Customary law refers to the system of rules and social regulations in existence in Maori society up to the assertion of British sovereignty in 1840. Prendergast could give limited recognition to aboriginal title, while dismissing the existence of any Maori customary law.

Prendergast's views on Maori customary law can be linked to his faith in Positivism. As Maori law did not strictly follow the Austinian requirements of being "commands issued by a sovereign backed by sanctions", it could not be properly classed as law. This approach by Prendergast was roundly criticised by the Privy Council in the 1900-1901 Nireaha Tamaki v Baker decision. ${ }^{50}$

This raises the possibility that Prendergast manipulated relevant precedent to reach a judgment favourable to contemporary colonial land policy. Analysis of Chief Justice Prendergast's judgment in Wi Parata could lead to a number of conclusions. Prendergast may have purposely engineered a line of legal reasoning to aid in the alienation of Maori land, or given a sincere but mistaken judgment in an effort to clarify a complex area of law. Alternatively, Prendergast may have provided an accurate decision in accordance with convincing precedent demonstrating wise and logical legal reasoning. Between the polarities of an ethnocentric conspiracy and a triumph of justice is where the answer lies. But whether intentional or not, Prendergast's decision had tragic consequences for Maori society for over one hundred years.

When analysing the Wi Parata case it is necessary to separate the various issues raised by Prendergast and explore each in turn and then how the issues relate to one another. First, the ratio of the decision deals with the nature of native or aboriginal customary title and its relationship to a Crown Grant. When discussing a Crown Grant, the ability of the Courts to question an Act of State is analysed. Secondly, the obiter dictum of the case deals with the Treaty of Waitangi and whether that document was an act of cession or a "simple nullity". Thirdly, Prendergast's decision must be seen in the context of contemporary international law: was it representative or not?

Prendergast has not made it easy for legal academics analysing the case. His language is verbose and convoluted, for example the sentence, "Such a qualification nullifies the proposition to which it is annexed." 51 In Wi Parata, the Chief Justice discussed a number of cases which have become high-profile in today's indigenous people's rights debate, including Johnson v McIntosh, ${ }^{52}$

49 Wi Parata, above n 1, 79.

50 Nireaha Tamaki v Baker, above n 29, 382.

51 Wi Parata, above n 1, 77.

5221 US (8 Wheat) 543; (1823) 5 L Ed 681 Marshall CJ. 
Cherokee Nation $v$ The State of Georgia ${ }^{53}$ and Queen $v$ Symonds. ${ }^{54}$ Also discussed are important New Zealand statutes such as the Land Claims Ordinance 1841, the English Law Act 1858 and the Native Rights Act 1865.

The legal historian must look beyond secondary commentaries on primary sources to the actual documents themselves. On the issue of aboriginal or native customary title and its relationship to a Crown Grant (ratio), Prendergast stated, "the right of extinguishing native title being exclusively in the Crown ... further, we are of opinion that the Court has no jurisdiction to avoid a Crown grant." 55 Therefore, Prendergast used the term native title, but argued that the Crown had complete authority to extinguish this title by issuing a Crown Grant and the Court could do nothing to prevent this. Crown sovereignty was supreme and "in the case of primitive barbarians, the supreme executive Government must acquit itself as best it may, of its obligation to respect native proprietary rights, and of necessity must be the sole arbiter of its own justice." 56 Transactions with the Maori "for the cession of their title to the Crown were thus to be regarded as acts of State, and therefore are not examinable by any Court." 57 Though he referred to native title, Prendergast was not convinced that it was a particularly relevant concept in that case as "there existed amongst the natives no regular system of territorial rights nor any definite ideas of property in land." 58

On the issue of the nature of the Treaty of Waitangi (obiter), Prendergast argued that the Treaty was not one of cession, "[n]o body politic existed capable of making cession of sovereignty." 59 Cession of sovereignty can only be made by a body that has sovereignty and Prendergast decided that "savages" did not have this vital power. Therefore the Treaty, as a legal instrument ceding sovereignty, was a nullity.

On the question of procedure, Prendergast decided that "a Crown grant cannot be avoided for a matter not appearing upon the face of the grant."60 The doctrine of cy prés was to be applied, meaning that the funds would be applied as near as possible to application specified by the donor, that is, the building of a school. This decision would cause ongoing legal actions in the Courts. Also, Prendergast decided that the Crown was the legal donor of the land, not the Ngati Toa, and if necessary the land would revert to the Crown.

\footnotetext{
53 (1831) 1 US Rep (S Peters) Marshall CJ.

54 Queen v Symonds, above n 44, 387.

55 Wi Parata, above n 1, 76-7.

56 Wi Parata, above n 1, 78.

57 Wi Parata, above n 1, 79.

58 Wi Parata, above n 1, 77.

59 Wi Parata, above n 1, 78.

60 Wi Parata, above n 1, 82.
} 
Therefore, the land originally belonging to the Ngati Toa, and then given to the Bishop of Wellington by a Crown Grant, remained with the Bishop. The Crown Grant was valid and native title could not undermine this fact and the Court could not question a Crown Grant. Wi Parata's case failed due to a host of legal reasons offered by Prendergast and Richmond. Prendergast's reasoning, though elucidated at length in the judgment, has been described by the leading legal academic in the field, Paul McHugh, as completely incorrect: "There were no portions of the judgment in which important errors of detail or interpretation did not occur." ${ }^{61}$ However, the decision has also been described by Auckland practitioner, Guy Chapman, as having, "stood the test of time. In its clarity of exposition, and basic soundness of judgment, it is fitting testimony to the quality of that most learned Chief Justice's judicial work." 62 With trained experts completely in disagreement over the judgment, it remains the most controversial legal decision in New Zealand history.

It is not the aim of this article to investigate in depth the national and international law relating to native or aboriginal customary title. This work has been extensively carried out by others, as discussed below. Their arguments are comprehensive and carefully researched and are supported by the Privy Council decisions from the early 1900s and also by the New Zealand High Court in the 1980s. The arguments against the existence of aboriginal title are brief and limited. That said, there appear to be two schools of thought on the matter, one supporting the doctrine of aboriginal title, led by the Privy Council and McHugh and one effectively dismissing the doctrine, led by Prendergast and certain English writers of the later nineteenth century, and supported by the New Zealand legal establishment up until the 1980s. In judicial decision-making it is possible to have a range of different precedents to follow, allowing a judge great flexibility. Prendergast used this flexibility in the law to decide Wi Parata. As to which school of thought will ultimately triumph, the law is in a constant state of flux, and therefore, the answer to that question is unclear.

In following the concept of Crown sovereignty, Prendergast was following a long line of established jurisprudential thinking, from Hobbes to Austin. In this respect, Prendergast was a judge of his time. It has only been during the twentieth century that jurisprudential schools of thought, such as the American Realists and Critical Legal Studies schools, have challenged the dominance of positivist thinking in the Western legal environment. If Prendergast had ignored the ultimate power of a Crown Grant, he would have been taking a liberal course in direct collision with New Zealand settler society. Prendergast was not the man to do this.

In his view of the Treaty, Prendergast's comments were extreme but were also obiter dicta, and therefore not technically a precedent. While always a key concern for Maori, the Treaty has only

61 Paul McHugh The Aboriginal Rights of the New Zealand Maori at Common Law (Ph D Thesis, University of Cambridge, 1987) 271.

62 Guy Chapman "The Treaty of Waitangi - Fertile Ground for Judicial (and Academic) Myth-Making" [1991] NZLJ 231. 
recently been recognised by wider New Zealand society as a vital constitutional document. For all the attacks made on the Wi Parata view, the Treaty of Waitangi is not in itself legally enforceable, although its principles have often been incorporated into New Zealand law by individual statutes. Prendergast's language regarding Maori society was unforgiving, but his desire to avoid allowing the Treaty to have a true part in the New Zealand legal system remains to this day. If one agrees with modern "orthodox" thought that the Treaty was one of cession, then Prendergast's view that is was "a simple nullity" is not correct, but, in terms of its legal power, the Treaty remains limited. The Treaty does not, in the positivistic sense, have intrinsic legality. The legal recognition of the principles of the Treaty is a far different matter from the legal recognition of the Treaty itself.

\section{THE INFLUENCE OF THE DECISION}

When the Wi Parata decision is described as the most notorious in New Zealand's history, this is with reference to the legal legacy of the case rather than just specific ethnocentric statements. Prendergast's 1877 decision in the Supreme Court created a precedent that resulted in the alienation of large amounts of Maori land. Effectively, any Maori land not bolstered by a Crown Grant could not be claimed using the doctrine of native title. Throughout the twentieth century, examples can be provided demonstrating the legacy of the Wi Parata decision. In 1909, Prendergast's reasoning was incorporated into statute form with the passing of section 84 of the Native Land Act 1909 and later the Maori Affairs Act 1953. ${ }^{63}$ Prendergast's judgment was relied upon to defeat Maori claims in several important twentieth century cases, for example, Re the Bed of the Wanganui River ${ }^{64}$ and Re Ninety-Mile Beach. ${ }^{65}$ The legal boundaries established by Prendergast were maintained and strengthened by many lawmakers who followed him.

The triumph of the Wi Parata line of reasoning was not without legal dispute, as demonstrated by the controversial Privy Council decisions in Nireaha Tamaki v Baker ${ }^{66}$ and Wallis v SolicitorGeneral. ${ }^{67}$ Analysis of these Privy Council decisions helps to place the reasoning of the New Zealand judiciary in a Commonwealth context. The Privy Council stated that it was "rather late in the day" to argue before a New Zealand Court that there was no customary Maori law which the courts could recognise, as had happened in Wi Parata. ${ }^{68}$ While the Privy Council harshly criticised

\footnotetext{
63 Haughey, above n 13, 231.

64 Re the Bed of the Wanganui River [1962] NZLR 600.

65 Re Ninety-Mile Beach [1963] NZLR 461.

66 Nireaha Tamaki v Baker (1900-01) NZPCC 371.

$67 \quad$ (1902-03) NZPCC 730.

68 Nireaha Tamaki, above n 66, 382.
} 
the actions of the New Zealand Supreme Court in a general manner, it stated that Wi Parata had been correctly decided on its own facts. Lord Davey of the Privy Council said: ${ }^{69}$

In the case of Wi Parata $v$ The Bishop of Wellington...the decision was that the Court has no jurisdiction by scire facias or other proceeding to annul a Crown grant for matter not appearing on the face of it, and it was held that the issue of a Crown grant implies a declaration by the Crown that the Native title has been extinguished. If so, it is all the more important that Natives should be able to protect their rights (whatever they are) before the land is sold and granted to a purchaser. But the dicta in the case go beyond what was necessary for the decision. Their Lordships have already commented on the limited construction and effect attributed to s. 3 of the Native Rights Act, 1865, by the Chief Justice in that case. As applied to the case then before the Court however, their Lordships see no reason to doubt the correctness of the conclusion arrived at by the learned Judges.

It was not until the mid-1980s that Prendergast's decision would be challenged directly. It could be argued that by this time the damage had been done.

Damage was done not only to Maori society but also to the relationship between the Judicial Committee of the Privy Council and the New Zealand Court of Appeal. The Wi Parata case formed the basis of the Wallis $v$ Solicitor-General case, in which the Privy Council severely criticised the conduct of the Court of Appeal. In an adjourned sitting of the Court of Appeal in Wellington on 25 April 1903, the Bench and the Bar of New Zealand defended themselves against the attack from London. On a day that would in future times represent the New Zealand legal profession's "coming of age", colonial lawyers and judges asserted their independence and raison d'etre.

Chief Justice Stout led the protest by defending the decisions of Prendergast, the Supreme Court and the Court of Appeal: "I feel the aspersions under the circumstances in which they have been made are a greater reflection on the Privy Council than on the Appeal Court of New Zealand."70 Stout CJ had not been part of the controversial Court of Appeal decisions as he and Edwards $\mathrm{J}$ had made the earlier Supreme Court decision which was successfully appealed. In fact, Stout CJ was congratulated by the Privy Council for his decision.

Williams J was more obviously indignant than Stout CJ, being one of the Court of Appeal judges responsible for the decision in question: ${ }^{71}$

If the Court had displayed subserviency or want of independence of the Executive it would have been loudly condemned by a unanimous public opinion. No suggestion of the kind has ever been made here.

It has been reserved for four strangers sitting 14,000 miles away to make it.... Whether, however, they

69 Nireaha Tamaki, above n 66, 383-4

70 "Wallis and Others v Solicitor-General, Protest of Bench and Bar, 25 April 1903" [1840-1932] NZPCC Appendix 730, 744.

71 "Wallis and Others v Solicitor-General, Protest of Bench and Bar, 25 April 1903", above n 70, 756. 
[decisions] should be reviewed by the Judicial Committee, as at present constituted is a question worthy of consideration. That Court, by its imputations in the present case, by the ignorance it has shown in this and other cases of our history, of our legislation, and of our practice, and by its long-delayed judgments, has displayed every characteristic of an alien tribunal.

William J's emotive challenge to the Privy Council could well have delayed his knighthood and elevation to the Council. William J defended the decisions of his former leader, Prendergast.

After a further indignant speech by Edwards J, Prendergast's associate, Travers, rose and stated that while he had not consulted his fellow lawyers, the Bar was in complete support of the Bench. As Travers spoke, the lawyers surrounding him rose to their feet and remained standing in a show of solidarity. ${ }^{72}$ Though attacked by the powerful Privy Council, the legal establishment of New Zealand closed ranks to protect its own and to protect the decision of James Prendergast. Even Prendergast's rivals, Stout and Edwards JJ, spoke openly in support of colonial independence and judicial loyalty.

In the case, Hohepa Wi Neera $v$ Bishop of Wellington, ${ }^{73}$ Stout CJ followed Prendergast's decision in Wi Parata. There was widespread support for Prendergast's views from the New Zealand judiciary for over a hundred years. Even New Zealand's greatest jurist, Sir John Salmond, supported the Wi Parata doctrine when he created section 84 of the Native Land Act 1909. ${ }^{74}$ The Wi Parata decision's legacy was diminished somewhat by the Hoani Te Heuheu Tukino $v$ Aotea District Maori Land Board decision, ${ }^{75}$ which recognised the Treaty as one of cession and not a simple nullity. But the decision supported Prendergast's claim that the Treaty could have no legal effect unless incorporated into statute. The judicial support for Wi Parata fell away only during the mid-1980s, a time of radical governmental change and judicial activism.

In 1986 Williamson $\mathrm{J}$ recognised Maori customary fishing rights and native title in Te Weehi $v$ Regional Fisheries Officer. ${ }^{76}$ This decision, according to some commentators, successfully challenged Prendergast's decision in Wi Parata. ${ }^{77}$ Paul McHugh heralded Williamson J's decision as the end of Prendergast's legacy: "The common law doctrine of aboriginal title has returned to

72 Travers was killed the following day in a railway accident.

73 (1902) 21 NZLR 655.

74 This section legislated that aboriginal title could not undermine a Crown Grant.

75 [1941] NZLR 590 (PC).

76 [1986] 1 NZLR 680.

77 Paul McHugh "From Sovereignty Talk to Settlement Time" in Paul Havemann (ed) Indigenous Peoples' Rights in Australia, Canada, \& New Zealand (Oxford University Press, Auckland, 1999) 458. 
New Zealand at the cost to the personal reputation of the primary adjudicator against it, Chief Justice Prendergast". ${ }^{78}$

While the Te Weehi case challenged Prendergast's views on aboriginal title, the landmark case, New Zealand Maori Council v Attorney-General, ${ }^{79}$ addressed another controversial issue raised by Wi Parata: the validity of the Treaty of Waitangi. This case concerned the effects of section 9 of the State-Owned Enterprises Act 1986 which declared that Government actions must accord with the principles of the Treaty. In interpreting what these principles were the President of the Court of Appeal, Cooke P, stated that "those principles require the Pakeha and Maori Treaty partners to act towards each other reasonably and with the utmost good faith." 80 The Wi Parata decision in relation to the Treaty was briefly discussed and criticised in the New Zealand Maori Council case. Bisson J stated that: "With the advent of legislation invoking recognition of the principles of the Treaty no longer is it to be regarded as a 'simple nullity' (as in Wi Parata v Bishop of Wellington)". ${ }^{81}$ Although the Court of Appeal has stressed that the Treaty does not have legal force except where incorporated by statute, the negative attitude to Prendergast's decision taken by modern legal leaders stands in contrast to the support Prendergast's decision received at the time it was made.

Six years after the Te Weehi decision had given recognition to the doctrine of aboriginal title, the High Court of Australia heard the landmark case, Mabo v Queensland (No 2). ${ }^{82}$ In this case, aboriginal title was discussed and recognised and the doctrine of terra nullius, the concept that Australia was not inhabited when discovered by Europeans, was cast aside. The idea of terra nullius is similar to Prendergast's statement in Wi Parata, that the South Island of New Zealand was acquired by "discovery".

The Wi Parata decision has been analysed and discussed at length in the reports of the Waitangi Tribunal. In the Orakei Claim report, the approach of Prendergast and Richmond was compared with that of Chapman J: "In Wi Parata the Court no longer spoke of 'aboriginal natives' or 'Maori New Zealanders' as Chapman $\mathrm{J}$ had done thirty years before, but of 'savages' and 'primitive barbarians."'83 This observation highlighted a generational change with regards to Maori issues between the 1840s and 1870s. "Liberal" judges such as Henry Chapman and William Martin had dominated the bench in the two decades after the signing of the Treaty. "Conservative" judges such

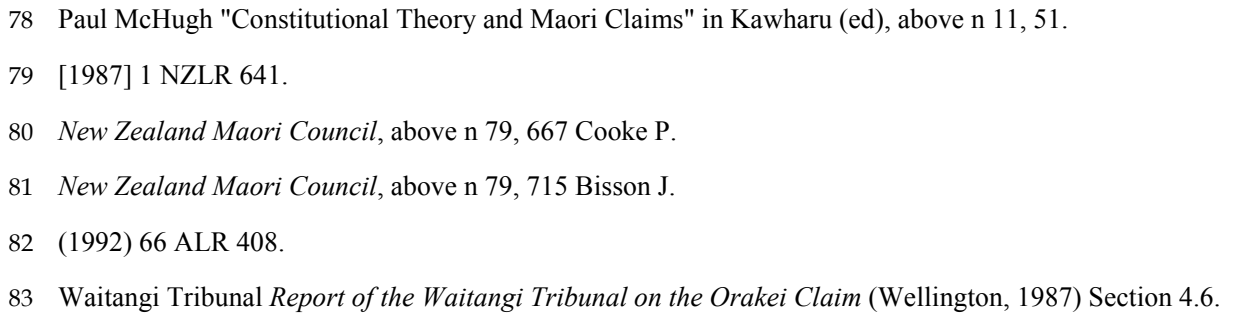


as James Prendergast and Christopher Richmond dominated the bench after the New Zealand Wars of the 1860 s.

The Orakei report claimed that the Privy Council contradicted the Wi Parata view in Nireaha Tamaki and Wallis but "[t]hereafter, and although the decisions of the Privy Council were meant to be binding, the New Zealand Courts pursued the Wi Parata view." 84 As mentioned earlier, while the Privy Council did criticise the Wi Parata decision, they also stated in Nireaha that Richmond and Prendergast had decided Wi Parata correctly on the facts. ${ }^{85}$

In the Kaituna River Claim, the Tribunal report relied heavily on the work of Paul McHugh and his argument that Prendergast's decision "was wrong being based on a concept of international law and not on the established principles of colonial law."86 The Ngai Tahu Sea Fisheries Report also referred to Wi Parata and discussed at length the conflict between the New Zealand Court of Appeal and the Privy Council during the early years of the twentieth century. ${ }^{87}$

Overall, the Waitangi Tribunal has taken an unfavourable view of the Prendergast decision, in line with the new "orthodox" view prevalent in Treaty jurisprudence, which is discussed in the next section. As mentioned in the Rangiteaorere Land Claim, the Tribunal reports cannot over-turn legal precedent nor are their recommendations binding on the New Zealand Government. ${ }^{88}$ Nevertheless, the opinion of the Tribunal and its researchers has much influence and the Tribunal reports have further served to undermine Prendergast's judicial reputation. The literature on the Treaty of Waitangi that has appeared over the past twenty-five years is vast and diverse. Numerous commentators, legal, academic, political and otherwise, have provided their viewpoints. In attempting to navigate this complex and often confusing mass of information, this author submits that an appropriate primary focus is the legal decisions and jurisprudential theory surrounding the Treaty of Waitangi.

Most recently, aboriginal title has been at the centre of the national debate following from the foreshore/seabed case decided by the Court of Appeal in June 2003. Wi Parata was referred to in the judgment of Elias CJ and subsequently dismissed: ${ }^{89}$

84 Orakei Claim, above n 83, s 4.6.

85 Nireaha Tamaki, above n 66, 384.

86 Waitangi Tribunal Report of the Waitangi Tribunal on the Kaituna River Claim (Wellington, 1984) s 5.6.10.

87 Waitangi Tribunal Report of the Waitangi Tribunal on the Ngai Tahu Sea Fisheries Claim (Wellington, 1992) s 5.14 .

88 Treaty of Waitangi Acts 1975 and 1985.

89 Ngati Apa v Attorney-General [2003] 3 NZLR 643, 663. 
... I am of the view that the approach taken by Turner $\mathrm{J}$ in the Supreme Court and by the Court of Appeal in In Re the Ninety-Mile Beach can be explained only on the basis that they were applying the approach taken in Wi Parata $v$ Bishop of Wellington. On that approach Maori property had no existence in law until converted into land held in fee of the Crown. Until then it was assumed to be Crown property... . For the reasons already given, such view is contrary to the common law and to successive statutory provisions recognizing Maori customary property.

There is clearly no place for Wi Parata in twenty-first century New Zealand law.

In Treaty jurisprudence, recent commentators have found it necessary to analyse the Wi Parata decision, either briefly ${ }^{90}$ or in-depth. ${ }^{91}$ The result of this analysis has been a largely negative view of Prendergast's decision. Therefore, the Wi Parata decision is arguably the most notorious in New Zealand's history, though this notoriety is a recent development. The lack of recognition given to the Treaty before 1975 is the principal reason for the relatively recent revisionist attention given to Prendergast's judgment by academics.

\section{ACADEMIC OPINION ON THE DECISION AND THE ROLE OF PRENDERGAST}

Recent academic opinion on Prendergast's decision in the Wi Parata case has been divided. This division has not been balanced, with most commentators condemning the decision as incorrect at best and manipulative ethnocentrism at worst. The critics of Prendergast's decision are vocal and numerous. In his ground-breaking research into the common law concept of aboriginal title, Paul McHugh dismissed Wi Parata as an example of misguided judicial activism. Far from following established law, Prendergast propagated the view of a small, unrepresentative group of English writers. $^{92}$ By disregarding the doctrine of aboriginal title, the Chief Justice steered New Zealand law off course for over a century. McHugh's research is of a jurisprudential nature and does not include comprehensive discussion about Prendergast himself. That said, Prendergast remains a key figure in McHugh's work. ${ }^{93}$

Academic arguments influenced Williamson $\mathrm{J}$ in his Te Weehi decision, highlighting the importance of Prendergast in New Zealand Treaty jurisprudence. His Honour needed to confront the legacy of James Prendergast before he could present his ground-breaking judgment. Another legal

90 Claudia Orange The Treaty of Waitangi (Bridget Williams Books, Wellington, 1987) 186-187.

91 For example, Paul McHugh The Maori Magna Carta: New Zealand Law and the Treaty of Waitangi (Oxford University Press, Auckland, 1991).

92 McHugh The Maori Magna Carta, above n 93, 113-114.

93 Paul G McHugh "A History of Crown Sovereignty in New Zealand" in Andrew Sharp and Paul McHugh (eds) Histories, Power and Loss: Uses of the Past - A New Zealand Commentary (Bridget Williams, Wellington, 2001) 189-211. 
academic, David V Williams, has also commented negatively on Prendergast's role in the Wi Parata decision. Williams described Prendergast's approach to Maori attempts to enforce the terms of the Treaty as "racial chauvinism". ${ }^{94}$ Unlike McHugh, Williams found similarities between Prendergast's viewpoint and that of other Commonwealth colonial judges. Sir James was not alone in his refusal to recognise indigenous rights. ${ }^{95}$ Legal boundaries were built by judges in other Commonwealth countries, including Australia and especially, South Africa.

A revisionist approach to Wi Parata is also seen in the works of F M Brookfield and Richard Boast. Brookfield takes a practical view of the Treaty stating the realities of Prendergast's legacy: ${ }^{96}$

I am a revisionist myself. But in any case, if the Treaty of Waitangi was a valid treaty in the international law of Western states, it is no longer in force as such: either the treaty itself or the ultimately successful assertions of imperial power that followed it extinguished the international personality of the chiefs.

In his analysis of the Wi Parata decision, Boast refutes several of Prendergast's claims: ${ }^{97}$

Prendergast CJ famously denied that Maori had any 'settled system of law'. This remark is not only untrue but is inconsistent with contemporary statutory directions to the Native Land Court in the Native Lands Acts that determinations of Maori title to land were to be made according to 'Maori custom'.

While the views of McHugh, Williams, Brookfield and Boast have attained some degree of orthodoxy in recent years, several commentators have argued the validity of Prendergast's now notorious decision. The most convincing argument vindicating Prendergast was presented by EJ Haughey, a former Maori Land Court Judge. Haughey emphasised the fact that Prendergast had only ruled in relation to Article One of the Treaty while seemingly confirming Article Two, which guaranteed Maori ordinary proprietary ownership. ${ }^{98}$ Haughey argued that the concept of territorial ownership found in Article One was significantly different to the concept of proprietary ownership found in Article Two. While Haughey stated that the Chief Justice was acting in accordance with well-established international law, his discussion is brief and lacks the complexity and depth of McHugh and Williams. Like the other commentators, Haughey does not delve deeply enough into the historical context of the Wi Parata decision and the role of James Prendergast.

94 Williams, above n 13,72 .

95 Williams, above n 13, 86-87.

96 F M Brookfield Waitangi and Indigenous Rights: Revolution, Law and Legitimation (Auckland University Press, Auckland, 1999) 99

97 Richard P Boast "'The Law and the Maori" in Peter Spiller (ed) A New Zealand Legal History (Brookers, Wellington, 1995) 127.

98 Haughey, above n 13, 230. 
The most controversial use of Prendergast's judicial legacy has been by Stuart C Scott. Scott's The Travesty of Waitangi, released in 1993, captured headlines, became a best seller and gained a reputation for being an anti-Treaty handbook. Scott used Prendergast's judgment to support his claim that the Treaty of Waitangi is not a valid document and should be ignored. Little legal argument is used by Scott, and Prendergast's usefulness is primarily in his "simple nullity" quotation. ${ }^{99}$ Scott's arguments are one-sided and poorly supported by primary evidence. While many commentators have accused Prendergast of building up legal boundaries, Scott defends the Chief Justice.

Scott's work is not convincing when compared with the other writers mentioned, but the popularity of The Travesty of Waitangi highlights the support for Prendergast's viewpoint in large sectors of the New Zealand community. The work of the Waitangi Tribunal in investigating Maori land claims relating to the Treaty of Waitangi has been extremely controversial and demonstrates the very real tensions still existing in New Zealand between Maori and Pakeha. The protests and disruptions surrounding Waitangi Day are further evidence of distinct differences in opinion over the nature of the Treaty. The issues surrounding the Treaty that Prendergast was faced with in 1877 are as important today as they were when Wi Parata was decided.

So Prendergast is still used by both sides in the debate over the validity of the Treaty of Waitangi. Pro-treaty writers condemn Prendergast as an ethnocentric imperialist, but usually in a few brief sentences. Anti-treaty writers see in Prendergast a credible champion for their views. While Scott is the most widely-known example, the conservative end of the Treaty jurisprudence spectrum also includes writers such as David Round and Guy Chapman. All their arguments focus on the Wi Parata decision.

David Round's view on the Wi Parata decision is in direct conflict to Paul McHugh's: $:^{100}$

The Treaty is a nullity in international law. This was so held in Wi Parata v Bishop of Wellington, and there is no reason to suppose that that case was not an accurate statement of international law as it was understood and practised last century.

But it was Guy Chapman's 1991 article in the New Zealand Law Journal that sparked an obvious pro-Treaty, anti-Treaty debate. Chapman supports Prendergast's "simple nullity" decision. ${ }^{101}$ The article by Chapman was rebutted by McHugh, Pita Rikys and Joe Williams later in 1991. ${ }^{102}$

99 Stuart C Scott The Travesty of Waitangi: Towards Anarchy (Caxton Press, Christchurch, 1995) 25.

100 David Round Truth or Treaty: Commonsense Questions About the Treaty of Waitangi (Canterbury University Press, Christchurch, 1998) 110.

101 Chapman, above n 62, 231.

102 Paul McHugh "Constitutional Myths and the Treaty of Waitangi" [1991] NZLJ 316; Pita Rikys "Trick or Treaty" [1991] NZLJ 370; Joe Williams "Chapman is Wrong" [1991] NZLJ 373. 
Radical scholarship on the Treaty of Waitangi has not been kind to Prendergast. "Radical" in this context refers to writers who express views challenging established, mainstream ideas. Prendergast's views on the Treaty and aboriginal title are seen as blatant support of the settler establishment. Writers such as Jonathan Lamb argue that Prendergast is just one oppressor in a long line: ${ }^{103}$

[T]here has been a Machiavellian theme, neatly summarised by Prendergast, which has justified the seizure of land by any finesse, deceit or force as requisite to a sound economy and stable polity. Its effect has been to privilege a land-owning elite that has consistently disguised its self-interest as bluff pragmatism and common sense.

Scholars such as Ranginui Walker ${ }^{104}$ refer negatively to Prendergast but not directly in relation to his Wi Parata decision. In an increasingly polarised debate, Prendergast is cast by pro-Treaty writers as a villain, while Chief Justice William Martin, for example, is cast as a hero. There are obvious historical problems with this polarised view: as this article reveals, the situation is more grey than black and white.

The term "orthodox" in relation to the Wi Parata decision is a controversial one. Havemann describes the views of Paul McHugh, who dismisses Prendergast's decision as incorrect, as orthodox. ${ }^{105}$ McDowell and Webb in The New Zealand Legal System describe Prendergast's decision as supporting the orthodox position: ${ }^{106}$

The orthodox view is that the Treaty is not one of cession, because the Maori did not possess any treatymaking capacity; that is, Maoridom was not a "state" recognisable in international law. This rule of international law was based on the assumption that native tribes did not possess any form of civil government capable of ceding sovereignty. This was recognised in New Zealand Courts in Wi Parata $v$ Bishop of Wellington.

As the debate continues, though, it is difficult to attach the word "orthodox" to the arguments of either side. Prendergast's view of the Treaty as a nullity was orthodox until Hoani Te Heuheu Tukino v Aotea District Maori Land Board ${ }^{107}$ stated that the Treaty could be enforceable in a Court but must have statutory recognition first. McDowell and Webb describe Hoani as the orthodox

103 Jonathan Lamb "The Idea of Utopia in the European Settlement of New Zealand" in Klaus Neumann, Nicholas Thomas and Hilary Ericksen (eds) Quicksands: Foundational Histories in Australia \& Aotearoa New Zealand (UNSW Press, Sydney, 1999) 80

104 Ranginui Walker Ka Whawhai Tonu Matou: Struggle Without End (Penguin Books, Auckland, 1990) 158.

105 Havemann, above n 77, 71; and Brookfield, above n 96, 99.

106 Morag McDowell and Duncan Webb The New Zealand Legal System: Structures, Processes and Legal Theory (2 ed, Butterworths, Wellington, 1998) 200.

107 Hoani Te Heuheu Tukino v Aotea District Maori Land Board [1941] NZLR 590. 
legal position: "the Treaty has been regarded by the Privy Council as a treaty of cession, and this, rather than Prendergast CJ's view, is probably the orthodoxy at the present time". ${ }^{108}$ The Treaty of Waitangi has not yet been given statutory recognition, though the principles of the Treaty have, so while scholarly thinking may support the legal legitimacy of the Treaty, legislation still does not.

The range of views on the Wi Parata decision mirrors the range of views found in wider Treaty jurisprudence. Several authors have attempted to provide summaries on the positions found in the Treaty debate. Examples include Paul Havemann in "The 'Pakeha Constitutional Revolution' Five Perspectives on Maori Rights and Pakeha Duties", ${ }^{109}$ Karl Upston-Hooper in "Slaying the Leviathan: Critical Jurisprudence and the Treaty of Waitangi"110 and David Williams in Te Kooti Tango Whenua: The Native Land Court 1864-1909.111 It is not the purpose of this article to repeat this work, but to relate it to Chief Justice James Prendergast and the Wi Parata decision.

The uniqueness of Prendergast's decision in a global context is a controversial issue in New Zealand legal historiography. Williams provides a number of examples from other Commonwealth nations, in particular, African countries such as Uganda and Swaziland, in an attempt to place the $W i$ Parata decision in global context. ${ }^{112}$ The conclusion reached is that Prendergast was not "a judicial pariah who wantonly disregarded the 'true' colonial law". ${ }^{113}$ Williams argues that Prendergast was also not alone in the British Empire in reaching decisions favourable to colonial governments. ${ }^{114}$ It is important that Prendergast be seen in a Commonwealth context, as New Zealand was only one of many British colonies during the nineteenth century. As already noted, Richmond aided in the formulation of the Wi Parata judgment, immediately dismissing the notion of a "one-man stand" by Prendergast. Both Richmond and Prendergast shared eurocentric views on indigenous people's rights.

In his role as Chief Justice, James Prendergast was the acknowledged leader of the New Zealand judiciary. Prendergast's views on Maori land differed from those of New Zealand's first Supreme Court judges, Chief Justice William Martin and Henry Chapman. The dismissal of the validity of aboriginal title in Wi Parata diverged from the more tolerant views of Martin and Chapman. But it does not follow that Prendergast was a poor representative of judicial attitudes during the mid to late

108 McDowell and Webb, above n 106, 204

109 (1993) 1 Waikato LR 53-77.

110 Karl Upston-Hooper "Slaying the Leviathan: Critical Jurisprudence and The Treaty of Waitangi" (1998) 28 VUWLR 683-717.

111 (Huia Publishers, Wellington, 1999).

112 Williams, above n 13, 66-75.

113 Williams, above n 13, 86.

114 Williams, above n 13, 86-87. 
nineteenth century. Both Chapman and Martin were criticised during their careers at the bench for favourable decisions towards Maori and may provide better examples of uncommon judicial attitudes than Prendergast. ${ }^{115}$ Prendergast's Wi Parata judgment stood virtually unchallenged by New Zealand judges until 1986. In comparison, Chapman's decision in Symonds lasted only thirty years before being superseded by Prendergast's judgment in 1877, demonstrating institutional and societal support for the Wi Parata decision.

In his Wi Parata decision, Prendergast described Maori as "primitive barbarians" and "savages". The inability to appreciate cultural difference due to ethnocentric biases was a common trait among those in positions of power in New Zealand during the late nineteenth century. Even leaders such as George Grey, steeped in knowledge of Maori society, took a paternalistic attitude towards Maori people. ${ }^{116}$ The few powerful, later nineteenth-century figures who fought for Maori rights, including William Martin and Governor Arthur Gordon, ${ }^{117}$ were often unpopular amongst other colonists. Gordon's outspoken support of Maori welfare helped to sour relations between himself and the settler government. Placed in historical context, Prendergast's views on Maori culture were not unique and show him to be a man of his times. These views did not prevent Prendergast from being widely admired by his peers and colleagues: in fact, quite the opposite.

Prendergast was praised by leading contemporary figures for his judicial integrity and dedicated leadership of the bench. ${ }^{118}$ Prendergast's loyalty to the British Empire and the New Zealand colonial government made him a highly respected and celebrated figure during the late nineteenth century. In contrast, Prendergast has recently featured in New Zealand historiography being criticised for his Wi Parata judgment and his support of the infamous Parihaka invasion. ${ }^{119}$ When these events occurred, Prendergast received the opposite reaction from many of his European peers.

115 Martin was criticised from some quarters for his support of the Maori cause and emphasis on the importance of the Treaty, as discussed by G P Barton in Oliver and Orange (eds) above n 6, 279.

116 See for example, Edmund Bohan To Be a Hero: Sir George Grey: 1812-1898 (HarperCollins, Auckland, 1998).

117 Gordon and Prendergast clashed over Prendergast's assenting to the invasion of Parihaka in 1881. Prendergast was Acting-Governor in Gordon's absence. James Prendergast, Chief Justice to W Jervois, Governor (27 January 1883) Governor's Papers (Wellington, National Archives, G17/95); and (4 September 1883) Governor's Papers (Wellington, National Archives, G17/9-21).

118 "Obituary" (28 February 1921) Dominion Wellington 4; "Obituary" (28 February 1921) Evening Post Wellington 6; "The Retiring Chief Justice" (1 June 1899) New Zealand Mail 41; "Presentation to Sir James Prendergast" (27 January 1883) New Zealand Mail 189.

119 Orange, above n 92, 202; and Ranginui Walker Ka Whawhai Tonu Matou: Struggle Without End (Penguin Books, Auckland, 1990) 158. 
In the latest general New Zealand history, Michael King made reference to Prendergast only in relation to the Chief Justice's description of the Treaty as a "simple nullity"120 Prendergast has been judged differently by different generations. The Chief Justice has been transformed from a hero to a villain. Prendergast lacked the humanitarianism of Martin and outspoken reputation of Gordon, but his present role as ruthless imperialist is undeserved.

\section{CONCLUSION}

In analysing the role of Prendergast in the Wi Parata legacy, the historian must be wary of judging the past by the values of the present. Prendergast may have been guilty of devastating ethnocentrism, actus reus, but continuing research suggests that he was less guilty, mens rea. The subjugation of the Maori race and the destruction of their culture was not the aim of James Prendergast. Instead, during his career in New Zealand, Prendergast hoped to help lay the foundations for a thriving colonial society, where Maori could play a limited and supporting role. The successful laying of foundations required the successful consolidation of British power. To a modern audience, this seems blatantly paternalistic, but it is far from genocidal.

While Prendergast's views of aboriginal title, Crown sovereignty and the legal status of the Treaty have been challenged over recent decades, the Treaty of Waitangi remains essentially an important constitutional document outside of the New Zealand law. The debate over its validity has become fierce and divisive, both in circles of power and wider New Zealand society. Instead of a legal ratio and accompanying dicta, the case has become a political weapon to be used at will by different factions in the Treaty debate. James Prendergast, the historical figure, has been lost in the chaotic war of words.

To dismiss the Wi Parata decision as completely incompetent and false is to dismiss one hundred years of historical support for Prendergast's viewpoint. If legally dubious, the decision was a reflection of political thought and settler desires. There is enough strength in the decision for it to retain substantial support from different sectors of the debate, but its power has been effectively reduced by decisions in the modern New Zealand courts.

The Wi Parata decision is in danger of becoming a simplified quotation, taken out of context as an example of the worst kind of racism. The case is complex and viewed in context, the quotation does not completely condemn the Treaty of Waitangi. While the legacy of the decision is tragic for the continued alienation of Maori land, several commentators argue that Prendergast was merely following established legal precedent, or, at least, attempting to follow it. James Prendergast was a man of his times, who displayed typical cultural superiority. Compared with the unconventional attitudes towards Maori rights held by judges such as William Martin, it is Prendergast's decisions that appear conventional.

120 Michael King The Penguin History of New Zealand (Penguin, Auckland, 2003) 325. 
Prendergast failed to rise above the prejudices of his society and quite possibly misunderstood the legal precedent surrounding indigenous people's land. The Wi Parata decision was not a triumph of justice and left a devastating legacy of Maori land alienation and economic breakdown. The legal boundaries created during Prendergast's Chief Justiceship have clearly influenced race relations throughout the late nineteenth and twentieth centuries. But Prendergast's decision was followed by many judges and incorporated into statute by many politicians who shared similar views to Prendergast.

Viewing the Wi Parata case in context provides a vital third dimension to this important historical event. Analysis of the motives and backgrounds of key players and the legal legacy of the decision transform the decision from a brief quotation to a historical incident, representative of its time and place in New Zealand's legal, political and cultural development.

There are a number of key relationships between the context of the Wi Parata decision and the decision itself. The privileged, conservative background of Prendergast placed him in a perfect position to take a course supporting the established elite of New Zealand colonial society. Every aspect of Prendergast's upbringing and career reflects English culture and society. There is virtually nothing in his personality, background and experience that could have prepared him to relate to Maori society.

An appreciation of the personal and professional relationships of the key figures in the $W i$ Parata decision is vital in understanding the decision. The judicial relationship between the new Chief Justice Prendergast and his older and more experienced colleague Richmond is fascinating and important. The effects of Prendergast and Richmond's feud with Barton and Prendergast's ties with Travers on the decision cannot be discounted as mere conspiracy theories. New Zealand politics in the nineteenth century was made up of a small number of men who worked and often socialised together. In 1870 s New Zealand settler society, political-legal figures such as George Barton and Wi Parata were "outsiders" while James Prendergast and William Travers were definitely "insiders".

The social and cultural background of the period is also vital in understanding the Wi Parata decision. The decision was not made in a vacuum, but rather in a fraught period following the bitter and devastating New Zealand Wars and the subsequent loss of Maori land. European immigration to New Zealand was occurring on a large scale and settlers were impatient to buy land and begin a new life in the colony. The settler political-legal establishment was focused on building a settler society based on farming and free from indigenous dissension.

The legal context of Wi Parata is also imperative to the outcome of the case. The law relating to native title was not clear in the 1870s and is still not clear today judging from the present legal controversy over Maori rights to the New Zealand foreshore and seabed. Wi Parata was a test case, not a case decided completely in isolation on its facts alone. There are roughly two divergent views on Wi Parata. One supporting Prendergast's decision and one damning it. The debate over the case 
has largely moved from the arena of law to the arena of politics. This article has sought to look at both the case and its historical context to promote a better understanding of just what happened in 1877, rather than what people would have liked to have happen if the case was decided over a hundred years later.

Chief Justice Sir James Prendergast does not deserve his role as the arch-villain of New Zealand legal history. Instead, Prendergast was a small player in a powerful social and cultural phenomenon beyond the influence of any one person: the implementation of the British legal system in a troubled land. 